\title{
A Contemporary on Indian Government Initiatives and Challenges of Warehouse Industry
}

\author{
Aravindaraj K, P. Rajan Chinna, Kalidhasan. M, Srinivasan. K
}

\begin{abstract}
Over the last six decades, Indian Logistics Sector has evolved a tremendous growth towards Indian economy ranges from the distribution management to integrated logistics management to supply chain management to $e$ - logistics. According to the Economic Survey 2018 report stated that the Indian logistics Sector is likely to touch USD 215 billion in 2020. According to Logistics Performance Index 2018, India slipped at 44th position from 35th position in 2016 out of 154 countries. This is due to the implementation of GST on July 1, 2017. Since many sectors in India are unorganized and fragmented sector. The impact of GST has been affected Indian economy during the initial period. But in coming years, there will be a tremendous growth and recently, the Government of India during union budget 2019 is now planned and focuses on 5trillion economy by 2024. Warehouse Sector is an integral part of the logistics sector and Indian Warehouse Market was ranked as fifth largest market in the Global Logistics Market. In this paper, we try to highlight the current scenario of warehouse market sector and also we try to deliver the current status of investment and infrastructure facilities in warehouse market in India. From a practical point of view, this paper points out the major challenges faced in warehouse sector market in India during recent years.
\end{abstract}

Keywords: Logistics, Warehouse, SAMPADA, FTWZ and Multi-Modal Logistics Park

\section{INTRODUCTION:}

Warehousing is often defined as the storage of goods prior to their use. According to Heskett, Ivie and Glaskowsky (1964), warehouse function is defined as "To the extent that inventory control is the heart of the logistics function, but warehouse is the actual centre of the logistics system for any firm" ${ }^{1}$ Normally, Logistics sector includes transportation, material handling and packaging, warehousing and enabling IT infrastructure which integrates all functions for the flow of goods between the point of origin and point of destination. Warehouse operation is the integral part of the logistics sector for enabling the storing of goods, demand in manufacturing

Revised Manuscript Received on July 22, 2019.

Dr. P. Rajan Chinna Assistant Professor in the Department of Logistics Management, Alagappa University, Karaikudi

Mr. M. Kalidhasan Doctoral Research Scholar in the Department of Logistics Management, Alagappa University, Karaikudi.

Mr. Srinivasan. K Assistant Manager at Royal Enfield, Chennai and doing his Part Time Doctoral Research Scholar in the Department of Logistics Management, Alagappa University, Karaikudi.

Aravindaraj. K Teaching Assistant and Part Time Doctoral Research Scholar in the Department of Logistics Management, Alagappa University, Karaikudi. sector and need of storage of raw materials, finished goods and non-finished goods from the manufacturing industries such as textiles, defense, food processing, automobiles and pharmaceuticals. In many manufacturing industries, warehousing sector has evolved significantly due to get a maximum benefit from the production to storage of goods. This warehouse sector is also play a vital role in the supply chain management. Since, warehouse process is carried out not only storage of goods in storekeeping but also minimizing the wastages and logistics costs.

According to the report from Ministry of Road Transport and Highways, Government of India has spends logistics cost approximately $14 \%$ of the GDP when compared to other developed countries. This higher cost is due to the inefficient of intermodal and multimodal transportation system in India when compared to other developed countries ${ }^{2}$. Warehousing sector in India also accounts approximately $25 \%$ of the logistics cost. Figure 1 shows the logistics cost as a \% of GDP in different countries.

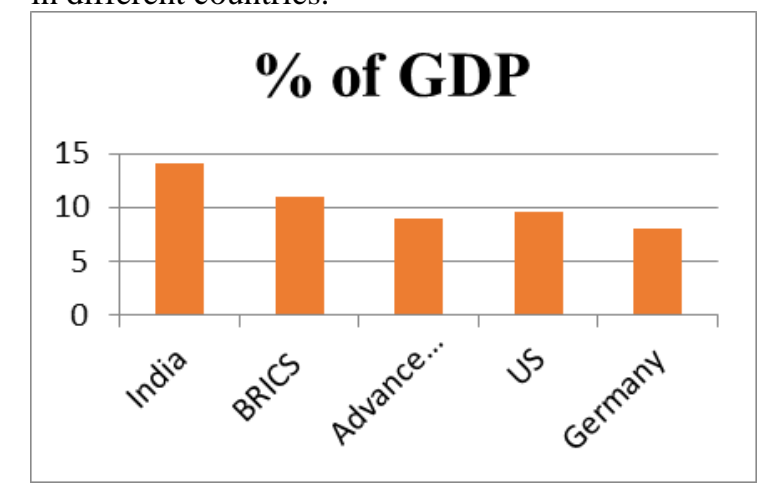

Source: Ministry of Road Transport and Highways

Figure 1 Logistics Cost as a \% of GDP.

The logistics sector in India is mostly dominated by the transportation sector which is accounted for nearly $85 \%$. Remaining $15 \%$ is done by the storage department i.e., warehousing sector. Figure 2 shows the logistics industry in India: Transportation Vs Storage. 


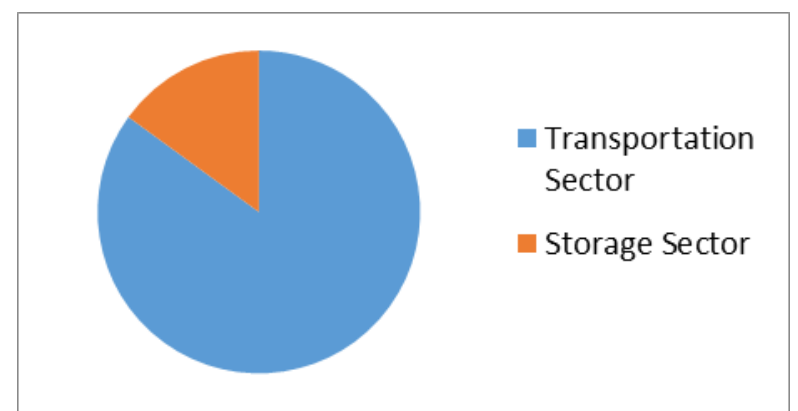

Source: Industry, IBEF

Figure 2 Logistics Industry in India: Transportation Vs Storage

The warehousing industry in India is worth Rs. 1,251 billion in 2018 and is growing at a 10-12\% of every year. This last four years, India saw the tremendous growth in Warehousing industry is due to the implementation of GST, Digital India - growth of e-commerce and digitization, Skill India programme, growing domestic consumption, 100\% FDI and increasing international trade. Figure 3 shows the growth of warehousing sector in India. From the figure, Indian warehousing sector is expected to reach Rs. 1,523 Billion in 2020 .

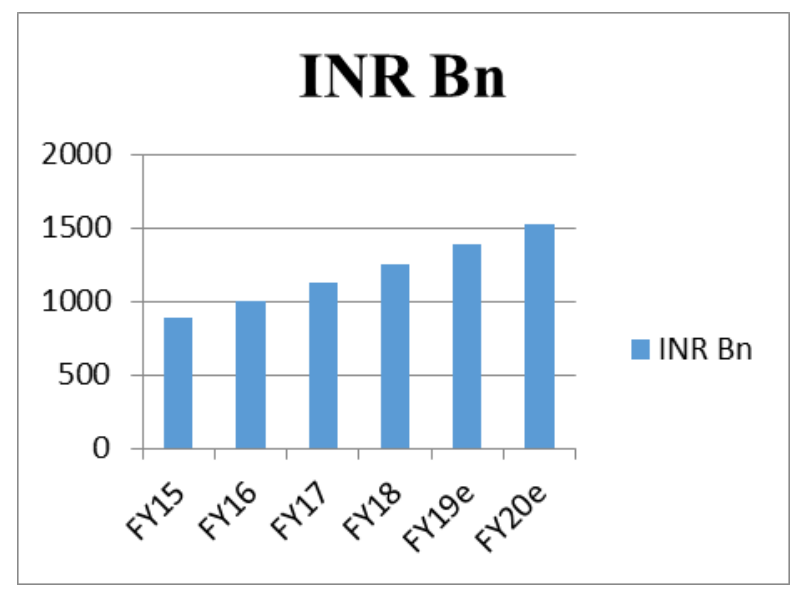

Source: Market Research, Report on Booming Warehouse Sector in India

Figure 3 Indian Warehouse Industry Growth

\section{OBJECTIVE:}

In this study, we are tried to highlight the following points. They are:

1. To know about the initiatives taken by the Government of India to nurture the growth of warehouse sector in India.

2. To know about the development of infrastructure facilities in warehousing sector in India.

3. To study about the major challenges faced in the warehousing sector in India.

\section{METHODOLOGY:}

This study is based on secondary sources of data and information. Different books, newspapers, magazines, journals, NITI AAYOG, IBEF, PIB, CARE ratings and websites have been consulted and identified in order to make the study in an effective manner. The study attempts to scrutinize the importance of warehouse sector in India.

\section{INITIATIVES TAKEN BY THE GOVERNMENT OF INDIA:}

The warehousing sector in India is highly unorganized and fragmented approximately $90 \%$ of the total market. This is due to most of the warehouse sector in India is having less than 10,000 sq.ft with result in high inventory holding costs, higher storage and improper material handling leads to damage of the product. Figure 4 shows the warehousing industry: organized Vs unorganized.

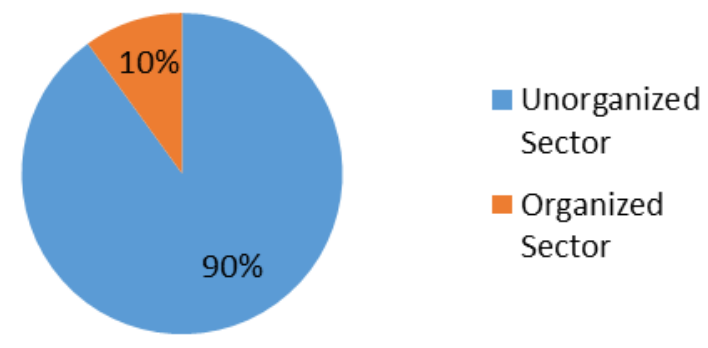

Source: Industry, IBEF

Figure 4 Warehousing Industry: Organized Vs Unorganized Sector

There are many initiatives taken by the Government of India to change the warehousing sector from unorganized to organized sector. Some of the initiatives like Make in India, Skill India, Digital India, GST and 100\% FDI will help in creating a hefty amount of investment in this sector.

Table I Initiatives taken by the Government of India in

Warehouse Sector

\begin{tabular}{|c|c|c|}
\hline S.No. & $\begin{array}{l}\text { Initiatives taken by } \\
\text { Government of India }\end{array}$ & Description \\
\hline 1. & Make in India & $\begin{array}{l}\text { 1. The main focus of this scheme is } \\
\text { strengthening the potential of the } \\
\text { manufacturing sector which helps in } \\
\text { creating jobs in all fields. } \\
\text { 2. This scheme also focused on setup } \\
\text { industrial corridors to promote } \\
\text { manufacturing clusters by connecting } \\
\text { them via intermodal and multimodal } \\
\text { transportation. There are five } \\
\text { industrial corridors are planned by the } \\
\text { Government of India. They are: } \\
\text { a. Chennai - Bangalore Industrial } \\
\text { borridor } \\
\text { Bangalore - Mangalore } \\
\text { c. Delhi - Mumbai Industrial } \\
\text { d. Amritsar - Kolkata Industrial } \\
\text { Corridor } \\
\text { e. Vizag - Chennai Industrial } \\
\text { Corridor }\end{array}$ \\
\hline
\end{tabular}




\begin{tabular}{|c|c|c|}
\hline 2. & GST & $\begin{array}{l}\text { 1. The major tax reform introduced on } \\
\text { July } 1,2017 \text { by the Government of } \\
\text { India. During the introduction phase, } \\
\text { warehousing industry faced a } \\
\text { problem due to most of the } \\
\text { warehouse industries are unorganized } \\
\text { and fragmented. } \\
\text { 2. The simplified GST will helps the } \\
\text { logistics cost reduced by } 2.5 \% \text { and } \\
\text { thereby reducing warehousing cost } \\
\text { and create a platform for higher } \\
\text { economic growth. }\end{array}$ \\
\hline 3. & $\begin{array}{l}\text { Multi- Modal Logistics } \\
\text { Park }\end{array}$ & $\begin{array}{l}\text { 1. Ministry of Road Transport and } \\
\text { Highways, Government of India has } \\
\text { planned } 35 \text { Multi modal logistics park } \\
\text { under Logistics Efficiency } \\
\text { Enhancement Program (LEEP). } \\
\text { 2. It will help the logistics sector by } \\
\text { lowering the logistics cost, traffic } \\
\text { congestion, cutting warehouse cost } \\
\text { and reduce carbon foot prints. }\end{array}$ \\
\hline 4. & FDI & $\begin{array}{l}\text { Government of India allows } 100 \% \text { FDI } \\
\text { towards warehouse sector in India. } \\
\text { 2. It will help the private sector provides a } \\
\text { higher investment and creates a lot of } \\
\text { opportunity for youngsters. }\end{array}$ \\
\hline 5. & $\begin{array}{l}\text { Pradhan Mantri Kisan } \\
\text { SAMPADA Yojana }\end{array}$ & $\begin{array}{l}\text { 1. SAMPADA means Scheme for } \\
\text { Agro-Marine Processing and } \\
\text { Development of Agro-Processing } \\
\text { Clusters. Government of India } \\
\text { allocates Rs. 6,000crore for the } \\
\text { period of } 2016-2020 \text { for this scheme. } \\
\text { 2. This scheme will give a big step } \\
\text { towards the ambitious project of } \\
\text { doubling farmer's income by } 2022 \text {. } \\
\text { This will be done by creating modern } \\
\text { infrastructure with efficient supply } \\
\text { chain management from farm produce } \\
\text { to the retail market. }\end{array}$ \\
\hline
\end{tabular}

\section{DEVELOPMENT OF INFRASTRUCTURE FACILITIES IN WAREHOUSE SECTOR IN INDIA:}

The logistics sector has been granted infrastructure status as cited by the Ministry of Finance, Shri Arun Jaitley on 2017. The Logistics infrastructure will allocate the investment as shown in table 5.1.

Table II Logistics Infrastructure

\begin{tabular}{|r|l|l|l|}
\hline S.No. & Scheme & $\begin{array}{l}\text { Minimum } \\
\text { Investment }\end{array}$ & Minimum Area \\
\hline 1. & $\begin{array}{l}\text { Multi Modal } \\
\text { Logistics Park }\end{array}$ & Rs. 50crore & $\begin{array}{l}10 \\
\text { Acre }\end{array}$ \\
\hline 2. & $\begin{array}{l}\text { Cold Chain } \\
\text { Facility }\end{array}$ & Rs. 15crore & 20,000 sq.ft. \\
\hline 3. & $\begin{array}{l}\text { Warehouse } \\
\text { Faciity }\end{array}$ & Rs. 25crore & 1lakh sq.ft. \\
\hline 4. & $\begin{array}{l}\text { Free Trade } \\
\text { Warehouse } \\
\text { Zone }\end{array}$ & Rs. 100crores & 5lakh sq.ft. \\
\hline
\end{tabular}

Free Trade Warehouse Zones (FTWZ) under the Ministry of Commerce and Industry comes under the category of special economic zones with focus on trading and warehouse. The objective of FTWZ is to create an infrastructure to facilitate the import and export goods and services with a freedom to carry out the transaction with free currency. According to JLL India report, there will be an investment of up to Rs. 50,000crore in creation of warehousing facilities in all states between 2018 and 2020 .

Cold storage facilities under the Ministry of Food Processing, Government of India came up an idea by implementing cold storage facilities for the perishable vegetables and fruits. Recent report stated that nearly $95 \%$ of cold storage facility is come from private sector and most of them are in small area. Remaining $5 \%$ of cold storage facility is owned by co-operatives and public sector. In India, there are over 7,700 cold storage facilities with an approximate capacity of about 36 million tonne.

According to the IBEF report, nearly $60 \%$ of the modern warehousing facility is concentrated on top eight cities in India viz., Chennai, Mumbai, Bangalore, Ahmadabad, NCR, Pune, Hyderabad and Kolkata.

Central Warehousing Corporation in India is operating of about 419 warehouse facility across India with a storage capacity of 10.1 Million tonnes.

\section{CHALLENGES FACED BY WAREHOUSE INDUSTRY IN INDIA:}

Besides an effort, initiative and investment during the past five years, the progress will be made on a phased manner which does not come without major challenges. The following factors which impact on warehouse industry in India. Some of the factors are:

1. Unorganized Sector: Warehouse industry in India is still in unorganized and fragmented. This is due to most of the warehouse sector in India is having less than 10,000 sq.ft with result in high inventory holding costs, higher storage and improper material handling which leads to damage of the product.

2. Transportation Sector: Transportation is the major problems in the warehouse sector due to delay in procurement materials. The transit time delay may loss the delay in production. Some of the problems in transportation sector are:
a. Pathetic road condition in rural areas.
b. Variation of fuel prices.
c. Minimum number of refrigerated fleet vehicle.
d. Lack of wireless technology and GPS facility.
e. Poor warehouse storage facility in major airports in India.

3. Availability of Workforce: Warehouse industry lacked trained personnel in India. It is difficult for the fresher who can operate material handling system and warehouse management system.

4. Availability of Land: Land allocation in India is a difficult task. Due to increase in real estate prices of land in and around major cities, procurement of land for warehouse industry is a tough.

5. Standardization: Most of the warehousing industries in India are less standardization. India's logistics sector has adversely affected due to lower standardization of cargo and material handling, increasing cost of storage and movement due to transit time delay.

6. Availability of IT: Most of the warehousing industries are unorganized. Hence, the availability of IT enabled services would be a minimal. Multi-modal and Inter-modal transportation infrastructure is yet to fully develop. 


\section{CONCLUSION:}

In this study, we tried to highlight the importance, initiative and challenges faced in warehouse sector in India. The entire study is based on the secondary source of data and information. Also no attempt is made on the analysis on issues and challenges of warehouse industry in India. Hence, there is enough scope of potential research on this topic. In last decade, warehouse sector in India market growth is increased by $10-12 \%$ of every year. This is happened due to the growth in manufacturing, retail and FMCG sectors. There is a development phase in recent years due to the implementation of GST, policy and regulation, integration of IT sector and e-commerce, hence warehouse sector in India will grow rapidly. However, the overall growth of warehouse industry is limited due to some key challenges like land acquisition, less standardization of handling material, infrastructure connectivity and less skilled labour which would need to be addressed soon to ensure the sustainable economic growth in India.

\section{REFERENCES:}

1. Abhishek Roy (2017). Warehousing in India: The Smart Way. The Warehouse Handbook.

2. Anchal Gupta, Pradeep Suri and Rajesh Kumar Singh (2018). Analysis of Challenges Faced by Indian Logistics Service Providers. Journal of Operations and Supply Chain Management. DOI: $10.31387 / \mathrm{oscm} 0350215$.

3. CARE Ratings (2018). Overview of the India Warehousing Industry.

4. Central Warehousing Corporation (2019). CWC at glance. Retrieved from http://cewacor.nic.in/index.php

5. IBEF (2018). Warehousing Industry may grow at $13-15 \%$ in medium term: Report. Retrieved from https://www.ibef.org/news/warehousing-industry-may-grow-at-1 315-in-medium-term-report

6. Knight Frank (2018). India Warehousing Market Report -2018.

7. Make in India (2018). Government Initiatives. Retrieved from http://www.makeinindia.com/five-things-to-know

8. Ministry of Commerce and Industry, Directorate General of Foreign Trade, Foreign Trade Policy 2015-2020. Report of Free Trade and Warehousing Zone. Retrieved from http://dgftcom.nic.in/exim/2000/policy/chap-7A.htm

9. Ministry of Commerce and Industry, India Services, Transport and Logistics $\quad$ Services. Retrieved from https://www.indiaservices.in/transport

10. Ministry of Finance (2018). Economic Survey Report 2018 - 19 Retrieved https://www.indiabudget.gov.in/economicsurvey/

11. Ministry of Food Processing Industries, Government of India. Pradan Mantri Kisan SAMPADA Yojana. Retrieved from http://mofpi.nic.in/Schemes/pradhan-mantri-kisan-sampada-yoj ana

12. NITI Aayog (2018). Goods on the Move: Efficiency and Sustainability in Indian Logistics.

13. Press Information Bureau, Ministry of Commerce and Industry, Government of India (2018). Investment in Logistics to Touch USD 500 Billion by 2025: Suresh Prabhu. Retrieved from http://pib.nic.in/PressReleaselframePage.aspx?PRID=1540616

14. Press Information Bureau, Ministry of Finance, Government of India (2017). Logistics Sector granted Infrastructure Status. Retrieved from http://pib.nic.in/newsite/PrintRelease. aspx?relid=173674

15. Rengamani. J and Venkatraman V (2015). Study on the developments of Industrial Warehousing in India. International Journal of Production Technology and Management. Volume 6, Issue 2, ISSN: 0976-6383.

16. Report Buyer (2017). Booming Warehouse Sector in India Outlook 2020. Report Id: 4613860.
17. Sathish K. Kapoor and Purva Kansal (2016). Basics of Distribution Management: A Logistical Approach. PHI learning private limited, Delhi.

18. Sneha Vishnu More (2016). The study of Efficiency and Effectiveness of Warehouse Management in the context of Supply Chain Management. International Journal of Engineering Technology, Management and Applied Sciences. Volume 4, Issue 8, ISSN 2349-4476. 